зованием свиней породы пьетрен, как улучшателя мясных качеств свиней. В свиней группы ВБ $\times$ ВБ и ВБ $\times$ М аллеля стресса не обнаружено.

Ключевые слова: свиньи, ДНК, ген RYR-I, «формалиновая пятно», стресс, адаптацุия.

\title{
STRESSITY PUREBRED AND CROSSBRED PIGS
}

Ivanov V. O., Guk M. S., Institute of Pig Production and Agro-Industrial Production of NAAS.

Stress factors play a negative role in the modern technology of weaned piglets. These actions caused uн lack of breast milk, loss of parent relations, change of litter, transportation to farms or internal rearrangement, changes of conditions of detention. Minor stress for animals can be a contributing factor to the health and stability of an organism to changing conditions. Strong stimuli have a negative effect on pigs that can lead to a deterioration of homeostasis, resistance, and at the final stage - the deterioration of productivity and animal disease. That is why our goal was to study the effect of stereses on animals in various genetic combinations.

At SE "EF Steppe" of Poltava region in order to identify the genetically determined features of the stress-sensitivity of purebred and crossbreed pigs, reseaches were performed using an immunological ("formalin spot" method during weaning piglets) and DNA tests (q.1843C>T polymorphism of RYRl gene study).

It was established that the greatest number of stres-sensitivity pigs were in the crossbreed group $B W \times(M \times 1 / 8 P)$. In the $B W \times B W$ group, in the presence of stresssensitive pigs, there were also stress-undetermined $B W \times B W$ pigs $-20 \%$. The part of stress-resistant animals in the group $B W \times M$ was $88 \%$, in the group $B W \times B W-80 \%$ and in the group $B W \times(M \times 1 / 8 P)-76 \%$, respectively.

The RYRI gene was investigated by polymerase chain reaction. It was found that pigs $B W \times(M \times 1 / 8 P)$ are carriers of the mutant allele of the stress $T(3 \%)$, which is manifested only in the homozygous state, and they are considered stress-resistant. The presence of T-allele is associated with the use of Pietrain pig breed, as an improver of meat qualities of pigs. For pigs of the group $B W \times B W$ and $B W \times M$, the stress allele was not detected.

Keywords: RYR-I gene, DNA, pig, adaptation, stress, "formalin spot".

DOI 10.32900/2312-8402-2019-121-127-136

УДК 636.52/.58.083.312.5

\section{ДОСЛІДЖЕННЯ ПАРАМЕТРІВ МІКРОКЛІМАТУ ПТАШНИКІВ ТА ХІМІЧНОГО СКЛАДУ ПОСЛІДУ КУРЕЙ ЗА ВИКОРИСТАННЯ КЛІТКОВИХ БАТАРЕЙ 3 РІЗНИМИ СИСТЕМАМИ ПОВІТРОВИДАЛЕННЯ}

\author{
Іщенко К. В., канд. с.-Г. н. \\ Харківський національний технічний університет сільського \\ господарства ім. Петра Василенка
}

Особливістю сучасного стану розвитку галузі птахівництва впродовж останнього десятиліття є динамічне зростання чисельності поголів'я птииі усіх видів, нарощування обсягів виробництва, збільшення внутрішнього попиту та ек- 
спорту продукиії. Поряд з цим, використання сучасного обладнання та технологій утримання птиці набувають все більш вагомого значення. Після проведення патентного пошуку та літературного аналізу можна зробити висновок про необхідність розробки технологічних прийомів, спрямованих на зменшення емісії аміаку та мікробного забруднення повітря у пташнику $і$ встановлення впливу їх застосування на продуктивні показники птиці.

Виходячи з изього метою науково-господарських експериментів було дослідження параметрів мікроклімату пташників та хімічного складу посліду курей за використання кліткових батарей з різними системами повітровидалення.

В дослідженнях хімічного складу посліду в залежності від термінів накопичення відмічено тенденцію до зменшення вмісту загального азоту у посліді при збільшенні термінів його накопичення на стрічкових транспортерах. Так, протягом 7-денного строку накопичення посліду в кліткових батареях з вбудованими повітропроводами вміст загального азоту в ньому зменшився на 7,5\%, з модернізованою системою підсушування посліду - на 5,7 \%, в кліткових батареях без повітропроводів - на 8,9\%. При изьому кількість фосфору $і$ калію коливалася у незначній мірі, і иі зміни були пов'язані, в основному, зі зменшенням відносної частки азоту. Встановлено, що протягом 7-добового терміну накопичення посліду на стрічкових транспортерах кліткових батарей вміст аміаку в повітрі збільшу-

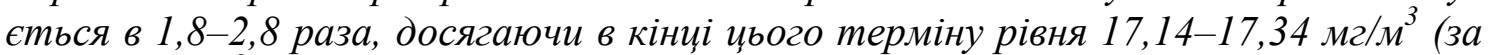

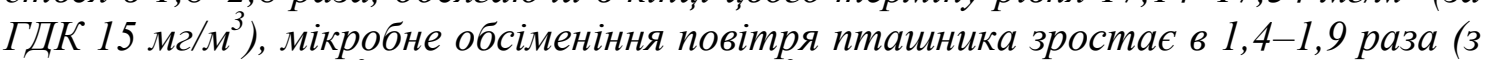

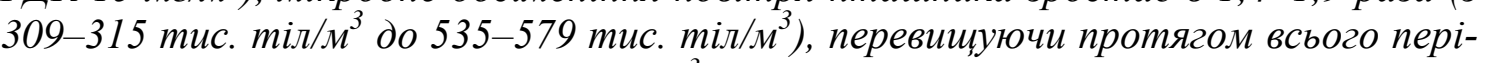
оду накопичення ГДК (220 тис. м.m./м $\left.{ }^{3}\right)$ в 1,2-2,6 раза.

Встановлено, шо при використанні кліткових батарей з вбудованими повітропроводами збереженість і продуктивність птичі були високо вірогідно вищими, ніж при використанні кліткових батарей без повітропроводів ( $\leq \leq 0,001)$. Ще вищими вони були при застосуванні кліткових батарей з модернізованим повітрозмішувачем: збереженість вище на 0,3\%, яєчна продуктивність на 1,6 шт., ніж при застосуванні кліткових батарей з типовими повітрообмінювачами.

Ключові слова: птахівництво, мікроклімат, кліткова батарея, повітровидалення, послід, аміак.

Птахівництво належить до тих галузей сільського господарства, розвиток яких дозволяє прискореними темпами поліпшити забезпечення зростаючого попиту населення на високоякісні продовольчі товари тваринного походження.

Галузь птахівництва є однією зі складових аграрного комплексу України, і iï перспектива, динамічний розвиток залежать від багатьох техніко-технологічних чинників. Так однією з проблем сучасних птахівницьких підприємств $є$ накопичення на їх території великої кількості посліду, який без прийняття належних заходів щодо його переробки та використання є джерелом забруднення довкілля токсичними речовинами і речовинами з неприємним запахом $[1,2]$.

В залежності від породних особливостей птиці, раціонів годівлі, типу обладнання, що застосовується, вихід посліду, його хімічний склад, вплив на навколишнє середовище можуть значно змінюватися.

Значну частину обладнання для вирощування та утримання птиці зараз становлять кліткові батареї застарілої конструкції з системою видалення посліду скребкового типу та жолобковими напувалками. При застосуванні таких кліткових батарей внаслідок протікання води з напувалок та вимушеного розбавляння посліду водою для полегшення прибирання з дослідних настилів отримують послід вологістю $82 \ldots 95$ \%. Розбавлення посліду водою призводить до погіршення 
мікроклімату у пташниках, збільшення виходу посліду, відповідно, транспортних витрат в 2-3 рази, негативного впливу на довкілля [3, 4]. Крім того, значно ускладнюється подальша переробка та використання посліду.

Враховуючи недоліки кліткових батарей з скребковим прибиранням посліду, все більшого поширення набувають кліткові батареї з стрічковою системою послідовидалення та ніпельними напувалками, які виключають потрапляння води 3 них у послід $[5,6]$. Такі кліткові батареї можуть постачатися з вбудованими повітропроводами, для підсушування посліду (потік повітря безпосередньо спрямований на стрічковий транспортер), або без вбудованих повітропроводів. При застосуванні кліткових батарей з стрічковою системою послідовидалення з підсушуванням послід прибирають один раз в 5-7 днів, а також вміст сухих речовин у посліді збільшується до 50 \%. У зв’язку зі зменшенням вологості посліду зменшуються його маса та витрати на транспортування, потреба у площах для зберігання, полегшуються подальша переробка та використання [7-9].

В той же час наведені в джерелах доступної науково-технічної інформації дані про застосування кліткових батарей з стрічковими системи прибирання посліду носять, скоріше, рекламний характер [10]. Відсутнє техніко-економічне обгрунтування оптимальних термінів накопичення посліду на стрічках транспортерів, режимів підсушування посліду, що забезпечують мінімальні втрати поживних речовин, інформація щодо отримання посліду з заданими властивостями, впливу підсушування посліду безпосередньо на птицю і якість яйця. Внаслідок цього експлуатація обладнання в птахівницьких підприємствах та використання отриманого підсушеного посліду часто відбуваються нераціонально.

Метою досліджень було вивчення кінетики сушіння посліду на стрічкових транспортерах кліткових батарей з різними системами повітровидалення та дослідження впливу термінів накопичення посліду на стрічках на хімічний склад посліду і мікроклімату у пташнику.

Матеріали і методи досліджень. У дослідах використовувалися сучасні багатоярусні кліткові батареї фірми «Hellmann» (Німеччина) для утримання курей-несучок $з$ вмонтованими повітропроводами системи підсушування посліду i без таких повітропроводів. Дослідження проводили в холодний і в теплий періоди року. Термін накопичення посліду на стрічкових транспортерах кліткових батарей становив 7 днів. Визначали динаміку вологості посліду, зміну його хімічного складу, параметрів мікроклімату у пташниках в залежності від термінів, сезонів року накопичення посліду на стрічкових транспортерах кліткових батарей. Параметри мікроклімату визначали за стандартними методами.

Результати досліджень. Встановлено, що як при використанні кліткових батарей із системою вентилювання стрічок так і без них, у літню пору забезпечувався більш високий ступінь підсушування посліду, що пояснюється більш високою температурою повітря у пташнику та повітря, що подавалося по повітропроводах у цей період. У свою чергу значно більш високий рівень підсушування посліду спостерігався при використанні кліткових батарей із системою вентилювання стрічок.

В холодний період року повітрообмін у пташниках підтримувався на рівні $0,7-1,2 \mathrm{~m}^{3} /$ год повітря в розрахунку на 1 кг живої маси птиці. Комп'ютер регулювання мікроклімату підтримував у пташнику задані параметри температури й вологості повітря, тому вони залишались однаковими протягом усього періоду накопичення посліду на стрічкових транспортерах. У той же час вміст аміаку у повітрі пташників збільшувався при збільшенні строків накопичення посліду й після 4-5 днів накопичення його рівень починав перевищувати гранично до- 
пустиму концентрацію - 15 мг у м³ повітря. Кількість аміаку на 7-й день накопичення посліду в усіх пташниках перевищувала його кількість у першу добу накопичення в $1,8-2,8$ рази $(\mathrm{p} \leq 0,001)$.

Вміст аміаку у пташнику з вентильованими стрічковим транспортерами у різні дні накопичення посліду був нижчим на 13-36 \%, ніж у пташнику з невентильованими стрічками. Кількість аміаку на 7-й день накопичення посліду в обох пташниках перевищував кількість його у першу добу накопичення в 1,9 рази. Більший вміст аміаку у пташнику 3 «невентильованими» стрічками пояснюється тим (і це підтверджують дані літературних джерел $[8,9])$, що з посліду більшої вологості аміачний азот втрачається швидше, ніж з більш сухого посліду.

Улітку температура у пташниках була вищою, а вологість повітря нижчою, ніж узимку. Повітрообмін підтримувався на рівні 5-6 м³/год на 1 кг живої маси птиці. Хоча процес підсушування посліду відбувався інтенсивніше, ніж узимку, завдяки значно більш інтенсивному повітрообміну концентрація аміаку в повітрі пташників була нижчою, ніж узимку. Разом з тим спостерігалася така ж тенденція до підвищення його кількості при збільшенні строків накопичення посліду.

Встановлене, також, підвищення мікробного забруднення повітря при збільшенні термінів накопичення посліду на стрічкових транспортерах кліткових батарей (рис. 1).

У випадку використання кліткових батарей без вбудованих повітропроводів 3 1-ої по 7-у добу накопичення посліду мікробне забруднення повітря підвищилось в 1,9 рази в холодний та в 1,7 рази в теплий періоди року. У випадку використання кліткових батарей з вбудованими повітропроводами мікробне забруднення повітря збільшилося дещо менше, в 1,7 рази в холодний період року та в 1,4 рази в теплий період. Більша мікробна забрудненість повітря при використанні кліткових батарей без системи підсушування в останні дні накопичення посліду пояснюється, на нашу думку, кращими умовами для життєдіяльності мікроорганізмів у більш вологому посліді.

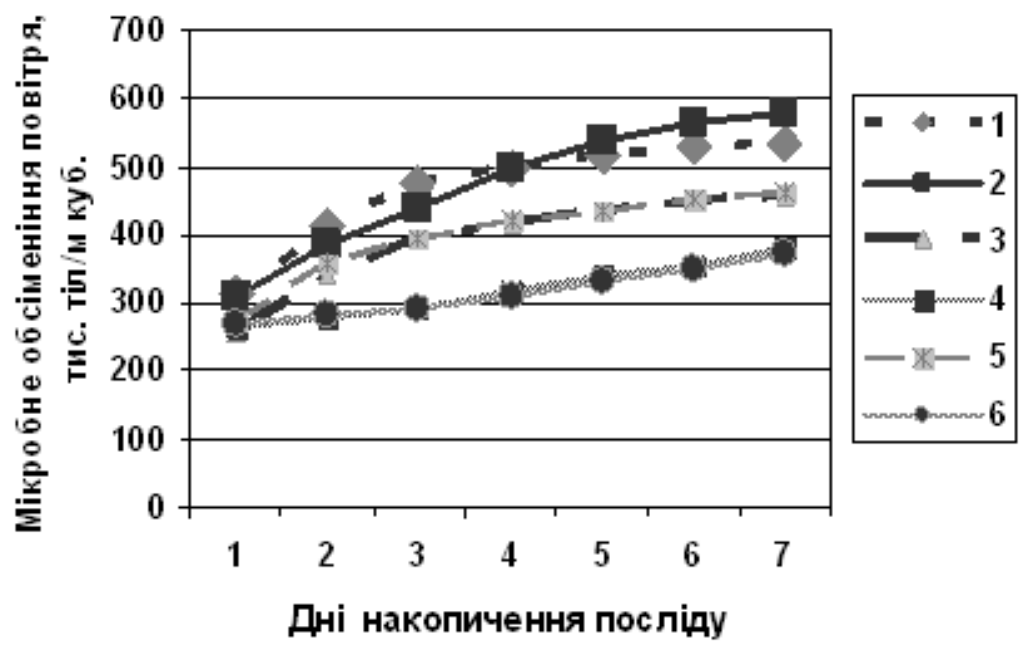

Рис. 1. Мікробне обсіменіння повітря у пташниках, обладнаних клітковими батареями зі стрічковою системою видалення посліду

1 - кліткові батареї з вбудованими повітропроводами в холодний період року; 2 - кліткові батареї без вбудованих повітропроводів в холодний період року; 3 - кліткові батареї з вбудованими повітропроводами та модернізованими повітрозмімувачами в холодний період року; 4 кліткові батареї із вбудованими повітропроводами в теплий період року; 5 - кліткові батареї без вбудованих повітропроводів в теплий період року; 6 - кліткові батареї з вбудованими повітропроводами та модернізованим повітрозмішувачем в теплий період року. 
В усіх випадках мікробне забруднення повітря перевищувало гранично допустимий ветеринарно-санітарними правилами для птахівницьких господарств рівень: (220 тис. тіл в 1 м $^{3}$ повітря пташників) в 1,2-2,6 рази, що свідчить про необхідність розробки заходів щодо його зменшення. Такими заходами могли б бути: встановлення у повітрозмішувачах фільтрів, бактерицидних ламп, обробка в них припливного повітря аерозолями дезінфектантів тощо.

Хімічний склад посліду в залежності від термінів накопичення, наведено у табл. 1-3.

Таблиияя 1

Залежність хімічного складу посліду від термінів накопичення на стрічкових транспортерах кліткових батареї 3 повітропроводами та типовими повітрозмішувачами

\begin{tabular}{|c|c|c|c|}
\hline \multirow{2}{*}{$\begin{array}{c}\text { Термін накопичен- } \\
\text { ня посліду, днів }\end{array}$} & \multicolumn{3}{|c|}{ Вміст в перерахунку на абсолютно суху речовину, \% } \\
\hline & Азоту & Фосфору & Калію \\
\hline Свіжий послід & $4,87 \pm 0,034$ & $2,86 \pm 0,042$ & $1,78 \pm 0,029$ \\
\hline 1 & $4,81 \pm 0,031$ & $2,87 \pm 0,038$ & $1,77 \pm 0,033$ \\
\hline 2 & $4,83 \pm 0,028$ & $2,86+0,035$ & $1,79 \pm 0,026$ \\
\hline 3 & $4,69 \pm 0,030 * *$ & $2,88 \pm 0,045$ & $1,67 \pm 0,037$ \\
\hline 4 & $4,70 \pm 0,041 * *$ & $2,84 \pm 0,037$ & $1,81 \pm 0,038$ \\
\hline 5 & $4,62+0,037 * * *$ & $2,81+0,043$ & $1,76+0,041$ \\
\hline 6 & $4,57+0,033 * * *$ & $2,84+0,039$ & $1,78+0,034$ \\
\hline 7 & $4,53+0,031 * * *$ & $2,83+0,042$ & $1,77+0,039$ \\
\hline
\end{tabular}

Таблиия 2

Залежність хімічного складу посліду від термінів накопичення на стрічкових транспортерах кліткових батареї з повітропроводами та модернізованими повітрозмішувачами

\begin{tabular}{|c|c|c|c|}
\hline \multirow{2}{*}{$\begin{array}{c}\text { Термін накопичення } \\
\text { посліду, днів }\end{array}$} & \multicolumn{3}{|c|}{ Вміст в перерахунку на абсолютно суху речовину, \% } \\
\cline { 2 - 4 } Своту & Фосфору & Калію \\
\hline Свіжий послід & $4,81 \pm 0,034$ & $2,97 \pm 0,032$ & $1,82 \pm 0,028$ \\
\hline 1 & $4,77 \pm 0,028$ & $2,93 \pm 0,039$ & $1,82 \pm 0,033$ \\
\hline 2 & $4,73 \pm 0,043$ & $2,89 \pm 0,041$ & $1,78 \pm 0,043$ \\
\hline 3 & $4,68 \pm 0,037$ & $2,95 \pm 0,039$ & $1,85 \pm 0,037$ \\
\hline 4 & $4,69 \pm 0,051$ & $2,88 \pm 0,036$ & $1,90 \pm 0,035$ \\
\hline 5 & $4,71 \pm 0,041$ & $2,90 \pm 0,037$ & $1,82 \pm 0,028$ \\
\hline 6 & $4,59 \pm 0,037 * *$ & $2,94 \pm 0,042$ & $1,85 \pm 0,036$ \\
\hline 7 & $4,55 \pm 0,038 * *$ & $2,93 \pm 0,028$ & $1,85 \pm 0,039$ \\
\hline \multicolumn{4}{|c|}{} \\
\hline \multicolumn{4}{|l|}{ Примітка. **- $p \leq 0,01 ; * * *-p \leq 0,001$ (у порівнянні зі свіжим посліоом). } \\
\hline
\end{tabular}

Дослідження виконувалися в холодний період року. Встановлено тенденцію до зменшення вмісту загального азоту у посліді при збільшенні термінів накопичення посліду на стрічкових транспортерах. Так, протягом 7-добового терміну накопичення посліду в кліткових батареях без повітропроводів вміст азоту в ньому зменшився на $0,39 \%$, із вбудованими повітропроводами та типовою системою підсушування посліду - на 0,34 \%, з модернізованою системою підсушуван- 
ня посліду - на 0,26 \%. Вміст фосфору і калію змінився у незначній мірі і ці зміни були пов'язані, в основному, зі зменшенням відносної частки азоту.

Таблиия 3

Залежність хімічного складу посліду від термінів накопичення на стрічкових транспортерах кліткових батареї без повітропроводів

\begin{tabular}{|c|c|c|c|}
\hline \multirow{2}{*}{$\begin{array}{c}\text { Термін накопи- } \\
\text { чення посліду, днів }\end{array}$} & \multicolumn{3}{|c|}{ Вміст в перерахунку на абсолютно суху речовину, \% } \\
\cline { 2 - 4 } & Азоту & Фосфору & Калію \\
\hline Свіжий послід & $4,76 \pm 0,041$ & $2,93 \pm 0,033$ & $1,80 \pm 0,026$ \\
\hline 1 & $4,64 \pm 0,039$ & $2,91 \pm 0,037$ & $1,80 \pm 0,029$ \\
\hline 2 & $4,58 \pm 0,037 *$ & $2,93 \pm 0,042$ & $1,81 \pm 0,033$ \\
\hline 3 & $4,50 \pm 0,038^{* *}$ & $2,93 \pm 0,039$ & $1,79 \pm 0,041$ \\
\hline 4 & $4,47 \pm 0,043^{* *}$ & $2,90 \pm 0,045$ & $1,82 \pm 0,035$ \\
\hline 5 & $4,42 \pm 0,037 * * *$ & $2,91 \pm 0,033$ & $1,80 \pm 0,037$ \\
\hline 6 & $4,39 \pm 0,029 * * *$ & $2,90 \pm 0,039$ & $1,82+0,027$ \\
\hline 7 & $4,37 \pm 0,035^{* * *}$ & $2,89 \pm 0,040$ & $1,82 \pm 0,033$ \\
\hline
\end{tabular}

Примітка. **- $p \leq 0,01 ; * * *-p \leq 0,001$ (у порівнянні зі свіжим послідом).

Було вивчено вихід посліду при утриманні курей кросу «Lohmann Brown». Встановлено, що при споживанні корму в середньому 112 г/гол. за добу вихід посліду коливався від 147,8 до 156,7 г/гол. за добу (в середньому 152,3 г/добу). Початкова вологість посліду коливалася від 66,9 до 72,6 \% ( в середньому 69,8\%).

Основні продуктивні показники курей-несучок при утриманні в кліткових батареях різного типу наведено в табл. 4.

Таблиия 4

Продуктивні показники курей-несучок кросу «Ломанн коричневий» в кліткових батареях різного типу

\begin{tabular}{|c|c|c|c|}
\hline $\begin{array}{c}\text { Найменування показ- } \\
\text { ників }\end{array}$ & \begin{tabular}{|c} 
Кліткові \\
батареї \\
без повіт- \\
ро- \\
проводів \\
\end{tabular} & $\begin{array}{c}\text { Кліткові батареї } 3 \\
\text { вбудованими повіт } \\
\text { ропроводами та ти- } \\
\text { повими повітро- } \\
\text { змішувачами } \\
\end{array}$ & $\begin{array}{c}\text { Кліткові батареї з } \\
\text { вбудованими повіт- } \\
\text { ропроводами та мо- } \\
\text { дернізованими пові- } \\
\text { трозмішувачами } \\
\end{array}$ \\
\hline $\begin{array}{l}\text { Кількість птиці у пта- } \\
\text { шнику, гол. }\end{array}$ & 47280 & 47280 & 47280 \\
\hline $\begin{array}{l}\text { Збереженість птиці за } \\
52 \text { тижні продуктивно- } \\
\text { го використання, \% }\end{array}$ & 93,7 & $94,8 * * *$ & $95,1 * * *$ \\
\hline $\begin{array}{l}\text { Отримано яєць в роз- } \\
\text { рахунку на початкову } \\
\text { несучку, шт. }\end{array}$ & 288,3 & $293,8 * * *$ & $295,2 * * *$ \\
\hline $\begin{array}{l}\text { Середня маса одного } \\
\text { яйця, г }\end{array}$ & $61,9 \pm 0,19$ & $62,7 \pm 0,24 * *$ & $63,3 \pm 0,21 * *$ \\
\hline $\begin{array}{l}\text { Яйцемаса, в розрахунку } \\
\text { на початкову несучку, кг }\end{array}$ & 17,845 & 18,421 & 18,568 \\
\hline $\begin{array}{l}\text { Витрати кормів, кг: } \\
\text { на } 10 \text { шт. яєць } \\
\text { на } 1 \text { кг яйцемаси }\end{array}$ & $\begin{array}{l}1,32 \\
2,13\end{array}$ & $\begin{array}{l}1,32 \\
2,11\end{array}$ & $\begin{array}{l}1,31 \\
2,10\end{array}$ \\
\hline
\end{tabular}

Примітка. ${ }^{* *}$ - $p \leq 0,01 ; * * *$ - $p \leq 0,001$ (у порівнянні з клітковими батареями без повітропроводів). 
При використанні кліткових батарей з вбудованими повітропроводами системи прибирання посліду продуктивність і збереженість птиці були дещо вищими, ніж при використанні кліткових батарей без повітропроводів. Різниця за збереженістю була також вірогідною між пташниками 3 типовими та модернізованими повітрозмішувачами на користь останнього. За утримання курей-несучок у пташниках з модернізованими повітрозмішувачами, в розрахунку на одну несучку було отримано на 1,4 яєць більше, ніж у пташниках 3 типовими повітрозмішувачами і на 6,9 шт. яєць більше, ніж у пташниках без системи вентилювання стрічкових транспортерів, маса яєць була більшою відповідно на 0,6 г і 1,4 г. Проте різниця за несучістю і масою яєць була вірогідною тільки між пташниками, в яких застосовувалися кліткові батареї з вбудованими повітропроводами (як 3 типовими повітрозмішувачами, так і з модернізованими) та без повітропроводів. При порівнянні пташників 3 типовою системою підсушування посліду та модернізованою спостерігалася тільки позитивна тенденція покращення продуктивних показників в останньому випадку. Перевага за продуктивними показниками курей-несучок, що утримувалися у пташниках з системою підсушування посліду, була наслідком, на нашу думку, кращих параметрів мікроклімату у цих пташниках.

Таким чином, виходячи з вищенаведеного, можна зробити висновок про необхідність розробки технологічних прийомів, спрямованих на зменшення емісії аміаку та мікробного забруднення повітря у пташнику і можливий позитивний вплив їх застосування на продуктивні показники птиці. Особливо важливе значення має вирішення цієї проблеми для холодного періоду року.

Проведені дослідження мікроклімату дають підставу для подальшого дослідження його впливу без посередньо на якість яєць.

\section{Висновки:}

1. Встановлено, що протягом 7-добового терміну накопичення посліду на стрічкових транспортерах кліткових батарей вміст аміаку в повітрі збільшується в

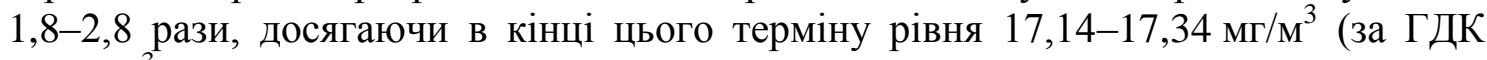
$\left.15 \mathrm{мг} / \mathrm{M}^{3}\right)$, мікробне обсіменіння повітря пташника зростає в $1,4-1,9$ рази (3 309-

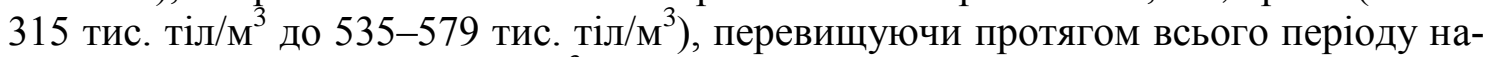
копичення ГДК (220 тис. м.т./м $\left.{ }^{3}\right)$ в 1,2-2,6 рази.

2. Встановлено, що при використанні кліткових батарей з вбудованими повітропроводами збереженість і продуктивність птиці були високо вірогідно вищими, ніж при використанні кліткових батарей без повітропроводів $(\mathrm{p} \leq 0,001)$.

\section{Бібліографічний список}

1. Vaarst M. Sustainable development perspectives of poultry production / M. Vaarst, S. Steenfeldt, K. Horsted // World's poultry science journal. - 2015. Vol. 71. - P. 609-620.

2. Neila B. S. Technology and Poultry Welfare / B. S. Neila, A. Xavier, E. Inma // Animals. - 2016. - Vol. 6, № 10. - P. 62.

3. Nahm K. H. Factors influencing nitrogen mineralization during poultry litter composting and calculations for available nitrogen / K. H. Nahm // World's poultry science journal. - 2005. - Vol. 61. - P. 238-255.

4. Kic P. Microclimatic conditions in the poultry houses / P. Kic // Agronomy Research. - 2016. - Vol. 14, № 1. - P. 82-90.

5. Палій А. Як зробити організацію напування в птахівництві оптимальною? / А. Палій, К. Іщенко // Птахівництво.иа. - 2018. - № 12. - С. 25-27. 
6. Pohle K. Comparative effects of furnished and battery cages on egg production and physiological parameters in White Leghorn hens / K. Pohle, H.-W. Cheng // Poultry Science. - 2009. - Vol. 88, № 10. - P. 2042-2051.

7. Al-Homidan A. Revier of the effect of ammonia and dust concentration on broiler performance / A. Al-Homidan, J. F. Robertson, A. M. Petchey // World's Poultry Science Journal. - 2003. - Vol. 59, № 3. - P. 607-610.

8. Тихончук Д. Комфорт на птицефабрике / Д. Тихончук // Сучасне птахівництво. - 2015. - № 9 (154). - С. 27-28.

9. Calvet $\mathrm{S}$. The influence of broiler activity, growth rate, and litter on carbon dioxide balances for the determination of ventilation flow rates in broiler production / S. Calvet, F. Estellés, M. Cambra-López, A. G. Torres, H. F. Van Den Weghe // Poultry Science. - 2011. - № 90. - P. 2449-2458.

10. Пешель Ж. OptiSec - тоннель для сушки помёта и биологических отходов / Ж. Пешель, А. Шварц // Птицеводство. - 2008. - № 5. - 59 с.

\section{References}

1. Vaarst, M., \& Steenfeldt, S., Horsted, K. (2015). Sustainable development perspectives of poultry production. World's poultry science journal, 71, 609-620.

2. Neila, B. S., \& Xavier, A., Inma, E. (2016). Technology and Poultry Welfare. Animals, 6(10), 62.

3. Nahm, K. H. (2005). Factors influencing nitrogen mineralization during poultry litter composting and calculations for available nitrogen. World's poultry science journal, 61, 238-255.

4. Kic, P. (2016). Microclimatic conditions in the poultry houses. Agronomy Research, 14(1), 82-90.

5. Palij, A., \& Ishhenko, K. (2018). Yak zroby`ty`organizaciyu napuvannya v ptaxivny`cztvi opty`mal noyu? [How to make the organization of drinking in poultry farming optimal?]. Ptaxivny`cztvo.ua. - Poultry breeding. ua, 12, 25-27 [in Ukrainian].

6. Pohle, K., \& Cheng, H.-W. (2009). Comparative effects of furnished and battery cages on egg production and physiological parameters in White Leghorn hens. Poultry Science, 88(10), 2042-2051.

7. Al-Homidan, A., \& Robertson, J. F., Petchey, A. M. (2003). Revier of the effect of ammonia and dust concentration on broiler performance. World's Poultry Science Journal, 59(3), 607-610.

8. Tihonchuk, D. (2015). Komfort na pticefabrike [Comfort at the poultry farm]. Suchasne ptahivnictvo - Contemporary Poultry Farming, 9 (154), 27-28 [in Ukrainian].

9. Calvet, S., \& Estellés, F., Cambra-López, M., Torres, A. G., Van Den Weghe, H. F. (2011). The influence of broiler activity, growth rate, and litter on carbon dioxide balances for the determination of ventilation flow rates in broiler production. Poultry Science, 90, 2449-2458.

10. Peshel', Zh. (2008). OptiSec - tonnel' dlja sushki pomjota i biologicheskih othodov [OptiSec - tunnel for drying manure and biological waste]. Pticevodstvo Poultry breeding, 5, 59 [in Russian].

ИССЛЕДОВАНИЕ ПАРАМЕТРОВ МИКРОКЛИМАТА ПТИЧНИКА И ХИМИЧЕСКОГО СОСТАВА ПОМЕТА КУРЕЙ ПРИ ИСПОЛЬЗОВАНИИ КЛЕТОЧНЫХ БАТАРЕЙ С РАЗЛИЧНЫМИ СИСТЕМАМИ ВОЗДУХОУДАЛЕНИЯ

Ищенко Е. В., Харьковский национальный технический университет сельского хозяйства им. Петра Василенко. 
Особенностью современного состояния развития отрасли птицеводства в течение последнего десятилетия является динамичный рост численности поголовья птицы всех видов, наращивание объемов производства, увеличение внутреннего спроса и экспорта продукиии. Наряду с этим, использование современного оборудования и технологий содержания птииы приобретают все более весомое значение. После проведения патентного поиска и литературного анализа можно сделать вывод о необходимости разработки технологических приемов, направленных на уменьшение эмиссии аммиака и микробного загрязнения воздуха в птичнике и установление влияния их применения на продуктивные показатели nтмиць.

Исходя из этого ичелью научно-хозяйственных экспериментов было исследование параметров микроклимата птичников и химического состава помета курей при использовании клеточных батарей с различными системами воздухоудаления.

В исследованиях химического состава помета в зависимости от сроков накопления отмечено тенденцию к уменьшению содержания общего азота в помете при увеличении сроков его накопления на ленточных транспортерах. Так, в течение 7-дневного срока накопления помета в клеточных батареях с встроенными воздуховодами содержание общего азота в нем уменьшилось на 7,5\%, с модернизированной системой подсушивания помета - на 5,7 \%, в клеточных батареях без воздуховодов - на 8,9\%. При этом количество фосфора и калия колебалось в незначительной степени, и эти изменения были связаны, в основном, $c$ уменьшением относительной доли азота.

Установлено, что в течение 7-дневного срока накопления помета на ленточных транспортерах клеточных батарей содержание аммиака в воздухе увеличивается в 1,8-2,8 раза, достигая в коние этого срока уровня 17,14-17,34 мг/м³

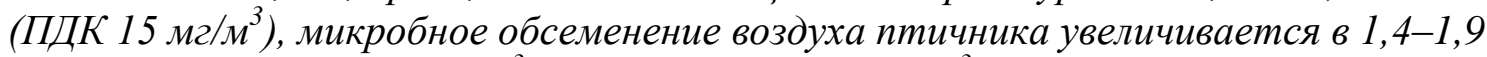

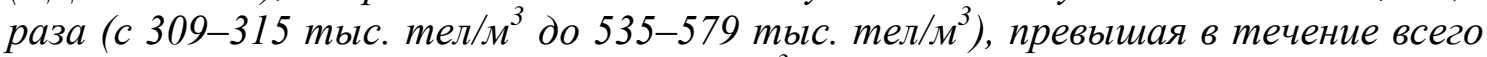
периода накопления ПДК (220 тыс. м.m / $\left.\mathrm{m}^{3}\right)$ в 1,2-2,6 раза. Установлено, что при использовании клеточных батарей со встроенными воздуховодами сохранность и продуктивность птииы были высоко достоверно выше, чем при использовании клеточных батарей без воздуховодов $(p \leq 0,001)$. Еще выще они были при применении клеточных батарей с модернизированным воздухосмесителем: сохранность выме на 0,3\%, яичная продуктивность на 1,6 шт., чем при применении клеточных батарей с типичными воздуховодами.

Ключевые слова: птицеводство, микроклимат, клеточная батарея, воздухоудаление, помет, аммиак.

RESEARCH OF PARAMETERS OF A CHARTER'S MICROCLIMATE AND A CHEMICAL WAY TO LAST CHICKENS FOR USE OF CELL BATTERIES WITH DIFFERENT SURFACE SYSTEMS

Ishchenko K., Kharkiv National Technical University of Agriculture Named after Petro Vasylenko.

The peculiarity of the current state of development the poultry industry during the last decade is the dynamic growth of the number poultry all kinds, increasing production volumes, increasing domestic demand and exporting products. In addition, the use of modern equipment and poultry keeping technologies is becoming increasingly important. After conducting a patent search and literary analysis, it can be concluded that it is necessary to develop technological methods aimed at reducing ammonia emissions 
and microbial air pollution in the poultry house and determining the impact of their application on the poultry productive indicators.

Proceeding from this, the purpose of scientific experiments was to study the parameters of the microclimate of poultry houses and the chemical bed of hens' litter for the use of cell batteries with various air systems removal.

In studies of the chemical composition of litter, depending on the terms of accumulation, a tendency towards a decrease in the total nitrogen content in the litter with an increase in the terms of its accumulation on the belt conveyors has been noted. Thus, during the 7-day period of accumulation of litter in cell batteries with built-in air ducts, the content of total nitrogen in it decreased by $7.5 \%$, with a modernized drying system of litter - by $5.7 \%$, in cell batteries without ducts - by $8.9 \%$. The content of phosphorus and potassium has changed to a small extent, and these changes were associated mainly with a decrease in the relative proportion of nitrogen.

It was established that within 7 days of accumulation of litter on the belt conveyors of cell batteries, the content of ammonia in the air increases by 1.8-2.8 times, reaching the level of $17.14-17.34 \mathrm{mg} / \mathrm{m}^{3}$ at the end of this period (in MPC $15 \mathrm{mg} / \mathrm{m}^{3}$ ), the microbial contamination of the air in the poultry house increases in 1,4-1,9 times (from 309-315 thousand bodies $/ \mathrm{m}^{3}$ to 535-579 thousand bodies $/ \mathrm{m}^{3}$ ), exceeding the whole period of accumulation of MPC (220 thousand $\left.\mathrm{mt} / \mathrm{m}^{3}\right)$ in 1,2-2,6 times.

It was established that when using cell batteries with built-in air ducts, the bird's safety and productivity were somewhat higher than when using cell batteries without air ducts ( $p \leq 0.001)$. Even higher were the use of cell batteries with a modernized air mixer: higher maintenance by 0,3\%, egg productivity by 1,6 pounds, than with the use of cell batteries with standard air vents.

Key words: poultry farming, microclimate, cell battery, air removal, litter, ammonia.

DOI 10.32900/2312-8402-2019-121-136-146

УДК 636.2.033.034.083.314:504.32

\title{
ТЕМПЕРАТУРА НАВКОЛИШНЬОГО СЕРЕДОВИЩА, ЯК ФАКТОР ВПЛИВУ НА ПРОДУКТИВНІСТЬ ВЕЛИКОЇ РОГАТОЇ ХУДОБИ
}

\author{
Кравченко Ю. С., К. с-Г. Н. \\ Прусова Г. Л., К. с-Г. н. \\ Золотарьов А. П., \\ Слецька Л. М., \\ Інститут тваринництва НААН \\ Тимченко Л.А. \\ Національна академія аграрних наук України.
}

У статті розглядаються питання впливу теплового стресу і високої температури навколишнього середовища на молочну і м'ясну продуктивність великої рогатої худоби різних порід.

Тепловий стрес у великої рогатої худоби, щуо виникає через поєднання таких умов як температура навколишнього середовища та вологість, створюють обстановку, щуо не дозволяє їм віддавати тепло. Разом з иим встановлено, щуо при негативному впливі високої температури навколишнього середовища включаєть- 